\title{
PENGEMBANGAN MULTIMEDIA PEMBELAJARAN INTERAKTIF MODEL TUTORIAL BERBASIS ADOBE FLASH MATERI CAHAYA SISWA SMP KELAS VIII
}

\author{
Ahmad Fatoni $^{1}$, Fahmi Yahya ${ }^{2}$, Sri Nurul Walidain ${ }^{2}$ \\ ${ }^{1,2,3}$ Prodi Pendidikan Fisika UNSA \\ E-mail: fatonisumbawa@gmail.com
}

\begin{abstract}
Abstrak
Penggunaan media pembelajaran yang kurang maksimal menyebabkan ketidaksesuaian antara konten dengan media yang digunakan. Hal ini perlu adanya pengembangan khususnya multimedia pembelajaran interaktif model tutorial berbasis Adobe Flash. Penelitian dan pengembangan ini bertujuan untuk mengetahui tingkat kelayakan, keterbacaan dan respon siswa terhadap multimedia pembelajaran interaktif model tutorial berbasis Adobe Flash. Jenis penelitian yang digunakan dalam penelitian ini adalah penelitian dan pengembangan dengan model pengembangan Borg \& Gall yang terdiri dari 10 langkah. Penelitian dan pengembangan ini dilakukan sampai pada tahap revisi produk operasional. Hasil penilaian terhadap tingkat kelayakan materi sebesar 98,1\% dan media sebesar $98 \%$ dengan kategori sangat layak. Hasil penilaian tingkat keterbacaan produk sebesar $96,5 \%$ dengan kategori tinggi. Hasil penilaian tingkat respon siswa sebesar 91,8\% dengan kategori sangat setuju.
\end{abstract}

Kata Kunci : multimedia pembelajaran interaktif model tutorial, Adobe Flash, cahaya

\section{PENDAHULUAN}

Pendidikan tidak terlepas dari proses belajar mengajar karena belajar merupakan kegiatan yang tidak akan pernah berhenti selama manusia masih hidup. Belajar dapat dipandang sebagai proses yang diarahkan kepada tujuan dan proses berbuat melalui berbagai pengalaman (Rusman, 2011:1). Salah satu alat untuk memudahkan proses belajar mengajar dalam rangka mengefektifkan komunikasi antara guru dan siswa yaitu melalui media pembelajaran. Karakterisitik media pembelajaran yang efektif dan efisien adalah memiliki lebih dari satu media misalnya menggabungkan unsur audio dan visual, bersifat interaktif, dan bersifat mandiri (Daryanto, 2015:55).

Media pembelajaran yang efektif dan efisien dapat memberikan arahan, bantuan, petunjuk, dan motivasi melalui bimbingan belajar disebut media pembelajaran tutorial. Bentuk pembelajaran tutorial dapat dilakukan oleh pembimbing yang terkualifikasi dalam penggunaan komputer sebagai media pembelajaran karena dengan adanya bimbingan tersebut membantu para siswa dalam memecahkan masalah belajar di kelas (Rusman, 2011:300). Salah satu software yang bisa dimanfaatkan dalam pembuatan media pembelajaran yaitu Adobe Flash. Program ini merupakan program animasi yang banyak digunakan oleh animator dalam menghasilkan animasi yang profesional (Istiqlal, 2011). Pelajaran fisika merupakan pembelajaran yang banyak memerlukan media khususnya materi cahaya karena materi ini berhubungan erat dengan kehidupan sehari-hari.

Berbagai kendala yang ditemukan dalam pembelajaran fisika di SMP Negeri 2 Sumbawa Besar khususnya pada media pembelajaran, yaitu tampilan dan penyajian materi yang kurang menarik perhatian siswa. Hal ini mengakibatkan respon siswa terhadap pembelajaran fisika masih rendah. Media pembelajaran masih berupa slide presentasi dalam bentuk gambar statis dan monoton. Selain itu, penggunaan media pembelajaran masih berpusat pada KIT praktikum yang ketersediaannya masih terbatas. Kegiatan praktikum hanya dilakukan pada topik-topik praktikum saja. Persediaan LCD masih terbatas sehingga penggunaan media pembelajaran kurang optimal. 
Berdasarkan fakta tersebut, alternatif dalam memecahkannya yaitu dengan mengembangkan media pembelajaran dalam bentuk multimedia pembelajaran interaktif yang menarik dan menyenangkan. Multimedia pembelajaran yang akan dikembangkan berupa penjelasan konsep-konsep fisika dalam bentuk audio, video, animasi, dan gambar yang bersifat interaktif dan dapat digunakan untuk belajar mandiri. Beberapa bukti-bukti penelitian dan pengembangan yang dilakukan sebelumnya oleh Priandana \& Asto (2015) yang mengatakan bahwa dengan menggunakan multimedia interaktif dalam proses pembelajaran mampu menarik perhatian siswa dan dapat memberikan manfaat terhadap siswa.

Penelitian lain juga dilakukan Ali (2009) bahwa multimedia pembelajaran interaktif dapat memberikan manfaat untuk melakukan belajar secara mandiri. Berdasarkan permasalahan dan data yang diperoleh di lapangan bahwa peneliti tertarik untuk melakukan penelitian yang berjudul Pengembangan Multimedia Pembelajaran Interaktif Model Tutorial Berbasis Adobe Flash Pada Materi Cahaya Siswa SMP Kelas VIII.

\section{TINJAUAN PUSTAKA}

Multimedia merupakan alat bantu dalam menyampaikan pesan dengan menggabungkan dua elemen atau lebih media, seperti teks, gambar, grafik, foto, suara, film, dan animasi secara terintegrasi (Kustandi \& Sutjipto, 2013:68). Ada beberapa jenis multimedia yang dapat digunakan, yaitu multimedia linier dan multimedia interaktif. Multimedia linier merupakan jenis multimedia yang tidak menggunakan pengontrol dalam pengoperasiannya, seperti film dan TV, sedangkan multimedia interaktif merupakan multimedia yang pengoperasiannya menggunakan kontrol-kontrol, seperti multimedia interaktif, dan aplikasi game (Daryanto, 2015:53). Penelitian dan pengembangan yang dilakukan ini menggunakan jenis multimedia yaitu multimedia interaktif karena dalam proses pengoperasiannya terdapat banyak kontrol-kontrol yang mengintegrasikan beberapa macam media dimana pengguna dapat belajar secara interaktif.

Model pada multimedia pembelajaran terbagi menjadi lima, yaitu: a) model tutorial yaitu penyampaian materinya dilakukan secara tutorial; b) model Drill and Practice yaitu untuk melatih siswa sehingga mempunyai kemahiran di dalam suatu keterampilan atau memperkuat penguasaan terhadap suatu konsep; c) model simulasi yaitu memberikan pengalaman masalah dunia nyata yang berhubungan dengan suatu resiko; d) model eksperimen yaitu kegiatan-kegiatan yang bersifat eksperimen, dan e) model permainan (games) yaitu media pembelajaran dengan model permainan (Daryanto, 2015:56). Model pembelajaran yang akan digunakan dalam pengembangan multimedia ini, yaitu model tutorial karena model ini memiliki karakteristik yaitu sebagai bahan ajar yang terprogram di dalam komputer, siswa dapat merespon dalam mempelajari materi tertentu, jawaban siswa dievaluasi oleh program pembelajaran di komputer, dan setiap kegiatan belajar, siswa perlu mengulang atau melanjutkan kegiatan belajar selanjutnya (Kustandi \& Sutjipto, 2013:70-71).

Program komputer yang digunakan dalam membuat media pembelajaran ini yaitu Adobe Flash. Adobe Flash merupakan sebuah program yang banyak digunakan oleh desainer ataupun programer dalam merancang animasi untuk membuat halaman web, presentasi untuk tujuan bisnis ataupun proses pembelajaran, pembuatan game interaktif dan tujuan-tujuan lain yang lebih spesifik (Dhanta, 2007:10). Salah satu kelebihan Adobe Flash yaitu bahasa scripting yang biasa disebut ActionScript yang mampu mendukung perancangan suatu animasi dari sederhana sampai yang kompleks dan juga dapat digunakan dalam pembuatan media pembelajaran (Pranowo, 2011:15-16). Media pembelajaran yang dikembangkan menyajikan materi fisika yaitu materi cahaya. Cahaya merupakan gelombang elektromagnetik berfrekuensi tinggi yang terdiri atas medan listrik dan medan magnet yang merambat tegak lurus dengan arah rambatnya (Giancoli, 2001:243). Cahaya memiliki sifat dualistik, artinya cahaya dapat berlaku sebagai gelombang pada keadaan 
tertentu dan dapat berlaku sebagai partikel pada keadaan tertentu (Serway \& Jewett, 2010:3-4).

\section{METODE PENELITIAN}

Penelitian ini menggunakan penelitian dan pengembangan dengan mengadaptasi model pengembangan Borg \& Gall. Prosedur yang dilakukan antara lain penelitian dan pengumpulan informasi, perencanaan, pengembangan produk awal, uji coba pendahuluan, revisi produk awal, uji coba terbatas, dan revisi produk operasional. Populasi dalam penelitian dan pengembangan ini adalah seluruh siswa SMP Negeri 2 Sumbawa Besar dengan sampel kelas VIII.

Uji tingkat kelayakan produk divalidasi oleh dua orang ahli isi dan dua orang ahli media dengan menggunakan angket. Uji tingkat keterbacaan produk diuji coba kepada 11 orang siswa dengan menggunakan tes rumpang. Uji tingkat respon siswa diuji coba kepada 11 orang siswa dengan menggunakan angket. Hasil uji tingkat kelayakan produk dianalisis menggunakan teknik perhitungan rata-rata dengan menggunakan kriteria yang dijelaskan oleh Akbar (2015:42) pada Tabel 1.

Tabel 1. Kriteria Kelayakan Produk

\begin{tabular}{|c|c|c|}
\hline Nilai Rata-rata & Kriteria Validasi & Keterangan \\
\hline $81,00 \%-100,00 \%$ & Sangat Layak & Dapat digunakan tanpa perlu revisi \\
\hline $61,00 \%-80,00 \%$ & Layak & $\begin{array}{l}\text { Dapat digunakan namun perlu } \\
\text { revisi kecil }\end{array}$ \\
\hline $41,00 \%-60,00 \%$ & Kurang Layak & $\begin{array}{l}\text { Tidak boleh digunakan karena } \\
\text { perlu revisi besar. }\end{array}$ \\
\hline $21,00 \%-40,00 \%$ & Tidak Layak & $\begin{array}{l}\text { Tidak boleh digunakan karena } \\
\text { perlu revisi besar-besaran }\end{array}$ \\
\hline $00,00 \%-20,00 \%$ & Sangat Tidak Layak & Tidak boleh digunakan \\
\hline
\end{tabular}

Hasil uji tingkat keterbacaan produk dianalisis menggunakan teknik perhitungan rata-rata dengan menggunakan kriteria yang dijelaskan oleh Jatnika (2007) pada Tabel 2.

Tabel 2. Kriteria Tingkat Keterbacaan Produk

\begin{tabular}{ll}
\hline Skor & Tingkat Keterbacaan \\
\hline Skor Tes $>\mathbf{6 0 \%}$ & Tinggi \\
Skor Tes $40-\mathbf{6 0 \%}$ & Sedang \\
Skor Tes $<\mathbf{4 0 \%}$ & Rendah \\
\hline
\end{tabular}

Hasil uji tingkat keterbacaan produk dianalisis menggunakan teknik perhitungan rata-rata dengan menggunakan kriteria yang dijelaskan oleh Akbar (2015:42) pada Tabel 3.

Tabel 3. Kriteria Respon Siswa

\begin{tabular}{ll}
\hline Persentase Jawaban & Kategori \\
\hline $81,00 \%-100,00 \%$ & Sangat Setuju \\
$61,00 \%-80,00 \%$ & Setuju \\
$41,00 \%-60,00 \%$ & Kurang Setuju \\
$21,00 \%-40,00 \%$ & Tidak Setuju \\
$00,00 \%-20,00 \%$ & Sangat Tidak Setuju \\
\hline
\end{tabular}




\section{HASIL DAN PEMBAHASAN}

Hasil validasi yang dilakukan oleh ahli dan guru terhadap tingkat kelayakan produk dari segi materi memiliki nilai rata-rata sebesar 98,1\%. Hasil validasi untuk tingkat kelayakan produk dari segi media memiliki nilai rata-rata sebesar $98 \%$. Berdasarkan hasil validasi yang dilakukan oleh ahli dan guru disimpulkan bahwa rata-rata penilaian produk dari segi materi dan media sangat layak. Data hasil uji tingkat kelayakan produk dapat dilihat pada Gambar 1.

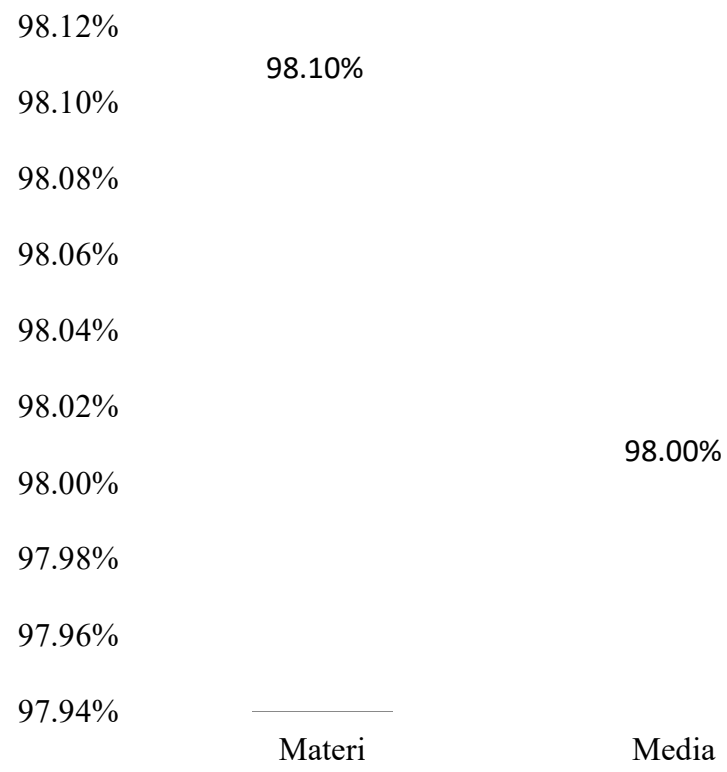

Gambar 1. Rata-rata Penilaian Ahli dari Segi Materi dan Media

Ada beberapa indikator penilaian yang dinilai tinggi oleh ahli dan guru fisika dari segi materi yaitu relevansi, keakuratan, dan kesesuaian sajian dengan tuntutan pembelajaran yang terpusat pada siswa. Selain itu, indikator yang dinilai masih kurang dari segi materi diantaranya kelengkapan sajian, sistematika sajian, kebahasaan, keterbacaan dan kekomunikatifan. Secara umum dapat disimpulkan bahwa materi pada multimedia pembelajaran interaktif model tutorial berbasis Adobe Flash sangat layak dan secara keseluruhan sudah mencakup materi-materi yang dipelajari di sekolah. Sedangkan, indikator penilaian yang dinilai tinggi oleh ahli dan guru fisika dari segi media yaitu desain, teks/tipografi, gambar, animasi, pengguna/user, keterbacaan dan kekomunikatifan, navigasi dan interactive link. Selain itu, indikator yang dinlai masih kurang dari segi media diantaranya layout, audio, dan video. Secara umum dapat disimpulkan bahwa media pada multimedia pembelajaran interaktif model tutorial berbasis Adobe Flash sangat layak dan sudah sesuai dengan karakteristik siswa untuk jenjang sekolah menengah pertama.

Hasil uji coba yang dilakukan terhadap 11 siswa untuk mengukur tingkat keterbacaan produk memiliki rata-rata skor tes sebesar 96,5\% dengan tingkat keterbacaan tinggi. Data hasil uji tingkat keterbacaan produk dapat dilihat pada Gambar 2. 
$105.00 \%$

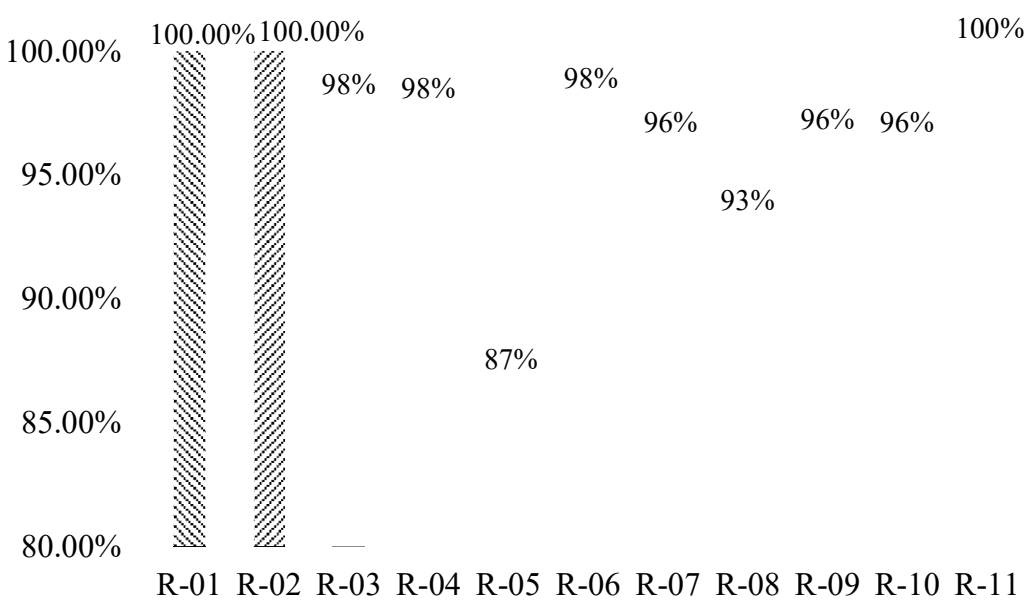

Gambar 2. Hasil Tingkat Keterbacaan Multimedia Pembelajaran Interaktif Model Tutorial Berbasis Adobe Flash

Hal ini disebabkan karena secara keseluruhan soal tes rumpang yang dijawab oleh siswa sudah benar. Siswa sangat tertarik dengan materi produk dan mendorong siswa untuk belajar sehingga soal yang diberikan kepada siswa mudah dijawab. Penyajian materi yang disajikan sudah sesuai dengan pernyataan soal sehingga siswa lebih mudah menjawab soal tersebut. Dapat disimpulkan bahwa multimedia pembelajaran interaktif model tutorial berbasis Adobe Flash dari tingkat keterbacaan sangat tinggi.

Hasil uji coba yang dilakukan terhadap 11 siswa untuk mengukur tingkat respon siswa memiliki rata-rata persentase penilaian sebesar $91,8 \%$ dengan tingkat respon sangat setuju. Data hasil uji tingkat respon siswa dapat dilihat pada Gambar 3.

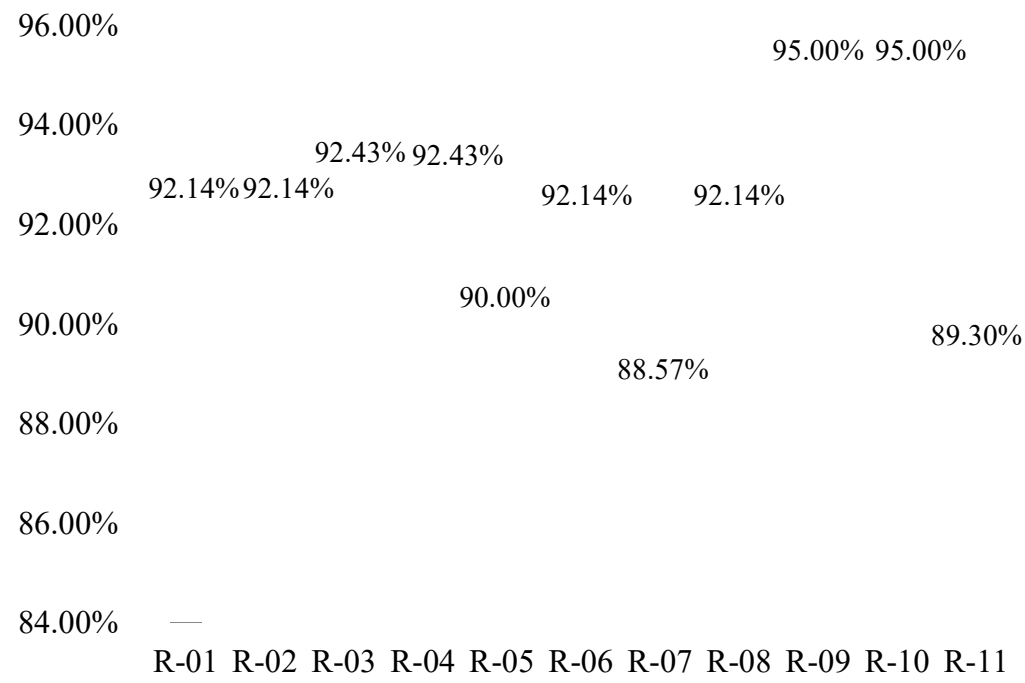

Gambar 3. Hasil Tingkat Respon Siswa Terhadap Multimedia Pembelajaran Interaktif Model Tutorial Berbasis Adobe Flash

Hal ini disebabkan karena sebagian besar siswa yang diberikan media pembelajaran yang peneliti kembangkan sangat antusias, menginginkan agar materi fisika yang lainnya menggunakan media pembelajaran seperti ini, dan juga siswa sangat berminat pada media 
pembelajaran tersebut. Proses pembelajaran yang biasa digunakan oleh guru di kelas yaitu dengan metode konvensional yang kadang-kadang menggunakan media pembelajaran. Jika dibandingkan dengan media pembelajaran yang biasa digunakan oleh guru di kelas, siswa merasa bosan karena tampilan media yang membuat jenuh siswa untuk belajar.

Selain itu juga, media yang digunakan oleh guru tidak dilengkapi dengan video pembelajaran. Sementara itu, gambar yang digunakan masih berupa gambar statis sehingga siswa susah untuk memahami materi yang disajikan dengan gambar yang ditampilkan. Dengan adanya pengembangan media pembelajaran seperti ini, terjadinya perubahan pola belajar siswa. Hal ini disebabkan siswa tidak dituntut lagi harus belajar dan mengerti materi di kelas tetapi siswa dapat belajar sendiri di rumah dan dapat mengevaluasi hasil belajarnya sendiri. Oleh karena itu, berdasarkan hasil respon siswa terhadap multimedia pembelajaran interaktif model tutorial berbasis Adobe Flash bahwa siswa sangat setuju media pembelajaran tersebut digunakan sebagai sumber belajar untuk belajar mandiri. Tampilan hasil produk pengembangan dapat dilihat pada Gambar 4 dan 5.

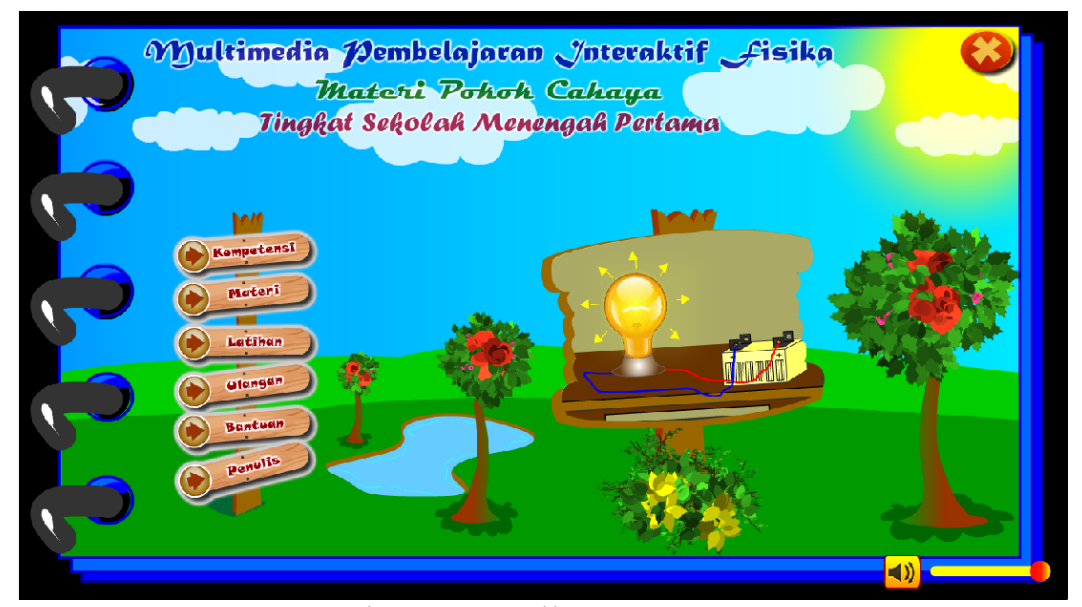

Gambar 4. Tampilan Menu Utama

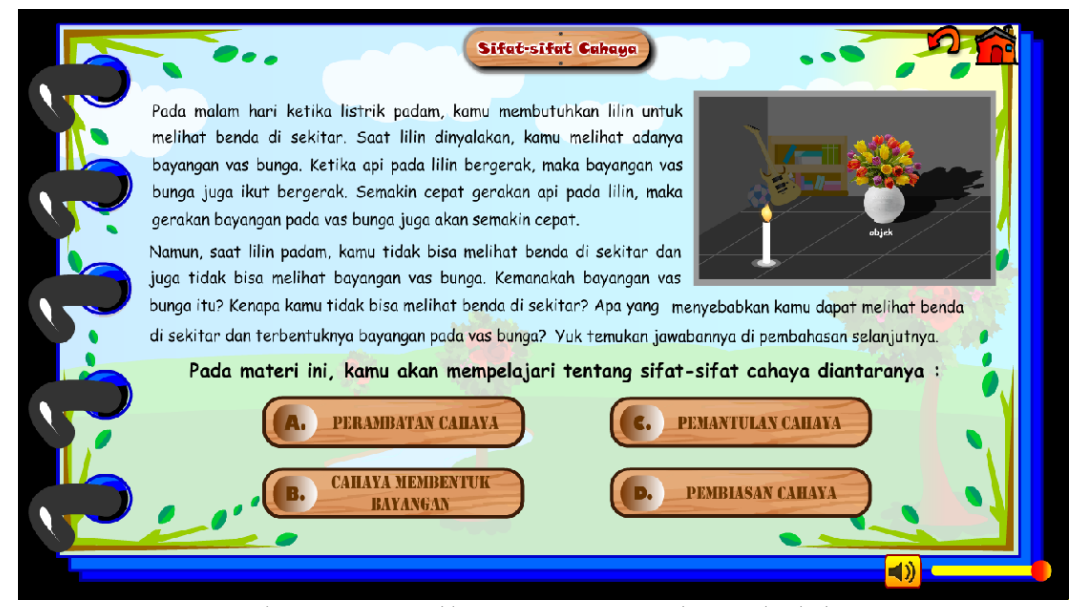

Gambar 5. Tampilan Menu Materi Pembelajaran

\section{KESIMPULAN DAN SARAN}

Berdasarkan hasil dan pembahasan dapat disimpulkan bahwa multimedia pembelajaran interaktif model tutorial berbasis Adobe Flash memiliki tingkat kelayakan yang sangat layak, tingkat keterbacaan yang tinggi, dan tingkat respon siswa yang sangat setuju. Media pembelajaran ini dapat digunakan oleh guru maupun siswa sebagai sumber 
belajar khususnya pelajaran fisika pada Standar Kompetensi (SK) memahami konsep dan penerapan getaran, gelombang, dan optika dalam produk teknologi sehari-hari dan Kompetensi Dasar (KD) menyelidiki sifat-sifat cahaya dan hubungannya dengan berbagai bentuk cermin dan lensa.

Multimedia pembelajaran interaktif model tutorial berbasis Adobe Flash ini memiliki tampilan menarik yang disertai dengan gambar, animasi, video, dan audio. Penyajian materi pada media pembelajaran ini dikembangkan berdasarkan pada model pembelajaran tutorial. Model tutorial menggunakan teori dan strategi pembelajaran dengan memberikan materi, contoh soal, pertanyaan, latihan ulangan, dan soal ulangan ulang. Tujuan dari model tutorial ini agar siswa dapat menyelesaikan suatu masalah serta dapat mengevaluasi pembelajaran secara mandiri.

Kekurangan multimedia pembelajaran interaktif model tutorial berbasis Adobe Flash adalah proses pengujian produk ini tidak sampai pada uji efektifitas tetapi hanya sampai pada tahap uji kelayakan, keterbacaan, dan respon siswa. Selain itu, uji coba yang dilakukan hanya pada skala kecil pada 11 siswa dan materi hanya membahas tentang pengertian cahaya, sifat-sifat cahaya, dan cermin. Oleh karena itu, untuk pengembangan lebih lanjut, proses pengujian tidak hanya sampai pada tahap uji respon siswa tetapi dapat menguji efektivitas media serta pengujian dilakukan pada uji coba operasional (uji coba pada skala besar). Selain itu materi produk tidak hanya dikembangkan pada satu materi saja, tetapi lebih banyak lagi materi yang disajikan karena pembelajaran fisika sangat banyak membutuhkan media pembelajaran.

\section{DAFTAR PUSTAKA}

Aji, R. B., N. Sidik R., \& S. Fatimah. 2015. Pengembangan Media Pembelajaran Fisika Berbasis Adobe Flash CS6 Dengan Pendekatan Contextual Teaching And Learning (CTL). Jurnal Kaunia. 9 (1): 79.

Ali, Muhamad. 2009. Pengembangan Media Pembelajaran Interaktif Mata Kuliah Medan Elektromagnetik. Jurnal Edukasi Elektro. 5(1):17.

Akbar, Sa'dun. 2015. Instrumen Perangkat Pembelajaran. Bandung: Remaja Rosdakarya.

Anitah, Sri. 2012. Media Pembelajaran. Surakarta: Yuma Pustaka.

Arsyad, Azhar. 2015. Media Pembelajaran. Jakarta: Rajawali Pers.

Daryanto. 2015. Media Pembelajaran. Bandung: Satu Nusa.

Dhanta, Rizky. 2007. Penuntun Lengkap Memakai Adobe Flash Profesional CS3. Surabaya: Indah.

Giancoli, D. C. 2001. Fisika Edisi Kelima Jilid 2 (Terjemahan Yuliza Hanum). Jakarta: Erlangga.

Hasrul. 2011. Desain Media Pembelajaran Animasi Berbasis Adobe Flash CS3 Pada Mata Kuliah Instalasi Listrik 2. Jurnal MEDTEK. 3(2):2.

Istiqlal, M., E., Ekawati, \& S. Fahmi. 2011. Pengembangan Media Pembelajaran Berbasis Multimedia Interaktif Menggunakan Adobe Flash CS3 Dalam Pembelajaran Matematika Standar Kompetensi Memecahkan Permasalahan Yang Berkaitan Dengan Sistem Persamaan Linear dan Pertidaksamaan Linear Satu Variabel Pada Siswa Kelas X. Makalah dipresentasikan dalam Seminar Nasional Matematika dan Pendidikan Matematika. Jurusan Pendidikan Matematika FMIPA UNY, Yogyakarta, 3 Desember 2011:481.

Jati, B. M. E. \& T. K. Priyambodo. 2010. Fisika Dasar Listrik-Magnet, Optika, Fisika Modern untuk Mahasiswa Ilmu-ilmu Eksakt \& Teknik. Yogyakarta: ANDI. 
Kustandi, C. \& B. Sutjipto. 2011. Media Pembelajaran Manual dan Digital. Bogor: Ghalia Indonesia.

Munir. 2013. Multimedia. Konsep \& Aplikasi dalam Pendidikan. Bandung: Alfabeta.

Nugroho, A. R, T. Raharjo, \& D. Wahyudiningsih. 2013. Pengembangan Media Pembelajaran Fisika Menggunakan Permainan Ular Tangga Ditinjau Dari Motivasi Belajar Siswa Kelas VIII Materi Gaya. Jurnal Pendidikan Fisika. $1(1): 12$.

Pelelupu, D. N. \& M. Cholik. 2014. Pengembangan Media Pembelajaran Berbasis Adobe Flash CS5 Pada Mata Diklat Gambar Teknik Di Kelas X TPM SMK Krian 1 Sidoarjo. Jurnal Penelitian Teknik Mesin. 3 (2):11.

Pranowo, Galih. 2011. Kreasi Animasi Interaktif dengan ActionScript 3.0 pada Flash CS5. Yogyakarta: ANDI.

Priandana, V. F. D. \& I G. P. Asto. 2015. Pengembangan Media Pembelajaran Multimedia Interaktif Berbantuan Software Macromedia Flash Pada Kompetensi Dasar Menerapkan Macam-Macam Gerbang Dasar Rangkaian Logika di SMK Negeri 2 Bojonegoro. Jurnal Pendidikan Teknik Elektro. 4(1):178-180.

Puspitosari, Heni A. 2010. Having Fun with Adobe Flash CS4 Professional. Yogyakarta: Intan Sejati Klaten.

Putra, Nusa. 2012. Research \& Development Penelitian dan Pengembangan: Suatu Pengantar. Jakarta: Raja Gravindo Persada.

Rusman. 2011. Model-model Pembelajaran Mengembangkan Profesionalisme Guru. Jakarta: Rajawali Pers.

Sanjaya, Wina. 2010. Penelitian Tindakan Kelas. Jakarta: Kencana.

Serway, R. A. \& W. J. Jewett. 2010. Fisika ntuk Sains dan Teknik (Terjemahan Chriswan Sungkono). Jakarta: Salemba Teknika.

Sugiyono. 2014. Metode Penelitian Pendidikan Pendekatan Kuantitatif, Kualitatif, dan $R \& D$. Bandung: Alfabeta.

Sugiyono. 2014. Statistik untuk Penelitian. Bandung: Alfabeta.

Sugiyono. 2015. Metode Penelitian \& Pengembangan Research and Development. Bandung: Alfabeta.

Taniredja, T. \& H. Mustafidah. 2014. Penelitian Kuantitatif Sebuah Pengantar. Bandung: Alfabeta. 